\title{
Periodontopathogens in the saliva and subgingival dental plaque of a group of mothers
}

\section{Periodontopatógenos na saliva e placa subgengival de um grupo de mães}

\author{
Odila Pereira da Silva Rosa* \\ Salete Moura Bonifácio da Silva** \\ Beatriz Costa** \\ Sérgio Aparecido Torres*** \\ Euloir Passanezi ${ }^{* * * *}$
}

\begin{abstract}
The aim of this study was to assess the periodontal condition and the presence of putative periodontal pathogens in 30 Brazilian mothers, aging 21-40 years (28.4 \pm 4.49 years), and in their children, aging 5-6 years, since mothers can be a source of pathogens and, thus, influence their children's bacteriological and clinical condition. Besides assessing the plaque index (PI), gingival index (GI) and pocket probing depth (PD), the survey analyzed four subgingival dental plaque samples from mothers and children, as well as a sample of stimulated saliva from mothers. Those samples were analyzed by means of the slot immunoblot (SIB) technique, in order to determine the presence of Actinobacillus actinomycetemcomitans (Aa), Prevotella nigrescens (Pn), Porphyromonas gingivalis (Pg) and Treponema denticola (Td). The mean values and standard deviations of the evaluated clinical variables for mothers and children were, respectively: $1.86 \pm 0.67$ and $1.64 \pm 0.68$ for PI, and $1.24 \pm 0.67$ and $0.82 \pm 0.37$, for GI. Only for mothers, the total PD was $1.81 \pm 0.69 \mathrm{~mm}$, and the PD of four sites was $4.03 \pm 1.40 \mathrm{~mm}$. The Wilcoxon test revealed significant difference ( $p<0.05$ ) between mothers and their children only as to GI. The most prevalent bacteria in mothers were, in decreasing order: Aa, Pn, Pg and Td. The children presented patterns of oral hygiene and bacterial profiles similar to those of their mothers, in spite of the fact that most of them did not present enough subgingival plaque for testing. The comparison between mothers' subgingival dental plaque and saliva samples revealed statistically significant differences $(p<0.05)$ for all bacteria, with greater positivity and scores in the saliva, which demonstrates that it is an indicator of oral colonization and can work as a vehicle for the transmission of periodontopathogens from mothers to their children.
\end{abstract}

DESCRIPTORS: Periodontal diseases; Communicable period.

\begin{abstract}
RESUMO: Procurou-se avaliar a condição periodontal e a presença de periodontopatógenos em 30 mães brasileiras, com idades entre 21-40 anos (28,4 \pm 4,49 anos) e seus filhos, com 5-6 anos de idade, considerando que elas possam ser fonte de transmissão para seus filhos e influenciar suas condições clínicas e bacteriológicas. Além de determinar o índice de placa (IP), índice gengival (IG) de mães e filhos, e a profundidade de sondagem periodontal (PS), apenas das mães, avaliaram-se quatro amostras de placa dental subgengival de mães e filhos e uma amostra de saliva total estimulada das mães para a presença de Actinobacillus actinomycetemcomitans (Aa), Prevotella nigrescens (Pn), Porphyromonas gingivalis $(\mathrm{Pg})$ e Treponema denticola $(\mathrm{Td})$, pela técnica de "slot immunoblot" (SIB). As médias e desvios-padrão para as variáveis clínicas em mães e filhos foram, respectivamente: 1,86 $\pm 0,67$ e 1,64 $\pm 0,68$, para o IP e 1,24 \pm 0,67 e 0,82 $\pm 0,37$, para o IG, enquanto apenas nas mães, a PS total foi 1,81 $\pm 0,69$ e a PS dos 4 sítios, $4,03 \pm 1,40$. O teste de Wilcoxon revelou diferença significante $(\mathrm{p}<0,05)$ entre mães e filhos apenas para o IG. As bactérias mais prevalentes nas mães, em ordem decrescente, foram, $A a, P n, P g$ e $T d$. As crianças demonstraram padrão de higiene oral e de ocorrência bacteriana semelhante aos de suas mães, apesar da maioria delas não apresentar quantidade suficiente de placa subgengival. A comparação entre amostras revelou diferença estatisticamente significante $(\mathrm{p}<0,05)$, com a saliva sempre exibindo os maiores valores e maior positividade, demonstrando ser um indicador de colonização oral e poder funcionar como veículo para a transmissão de periodontopatógenos de mães para filhos.
\end{abstract}

DESCRITORES: Doenças periodontais; Período de transmissibilidade.

*PhD, Associate Professor, Discipline of Microbiology; **PhD, Professor, Discipline of Pedodontics; ***PhD, Professor, Discipline of Microbiology; ${ }^{* * * *} \mathrm{PhD}$, Chairman, Discipline of Periodontics - School of Dentistry of Bauru, University of São Paulo. 
Rosa OP da S, Silva SMB da, Costa B, Torres SA, Passanezi E. Periodontopathogens in the saliva and subgingival dental plaque of a group of mothers. Pesqui Odontol Bras 2002;16(4):313-318.

\section{INTRODUCTION}

If the first years of life are critical in relation to the acquisition of certain types of bacteria, it is much likely that many children acquire microorganisms from their parents or other people with whom they have a close relationship.

Maternal or intrafamilial transmission has been considered a conceivable means of infection in children, and the saliva, a major vector of bacterial transmission ${ }^{7}$. Nevertheless, there are relatively few studies on the presence of putative periodontopathogens in the saliva ${ }^{1,2,3,6,7,10,12,13,14,19,22,24}$. Thus, it is interesting to assess the prevalence of some periodontopathogens in children aging 5-6 years and in their mothers - since the latter can be a source of transmition of pathogens to their children - and to analyze whether there is a correlation between microbiological and clinical indicators for both groups.

\section{MATERIALS AND METHODS}

Thirty mothers aging 21 to 40 years and their children, aging 5 to 6 years, all from Bauru, State of São Paulo, Brazil, comprised the sample of this study. The participants signed written informed consents, and the research protocol was approved by the Ethic Committee, School of Dentistry of Bauru, University of São Paulo. The subjects presented good general health, had not undergone antibiotic therapy during the past three months, and did not wear orthodontic or prosthetic appliances. Clinical examination comprised the determination of plaque (PI) and gingival (GI) indexes ${ }^{9}$, for mothers and children, as well as periodontal probing throughout the mouth, for mothers.

\section{Collection of samples}

Five samples were collected from mothers. Four of them were composed of dental plaque from the deepest pocket of each quadrant, or, in normal conditions, from the lingual aspect of first lower molars and from the buccal aspect of first upper molars; the other sample consisted of saliva. After careful removal of supragingival plaque, the subgingival plaque from each area was gathered with the aid of a sterilized curette and placed in cryotubes containing $0.5 \mathrm{ml}$ of transport and maintenance solution (Complete, Boehringer Mannheim). For the obtainment of the stimulated total saliva sample, the subjects chewed a sugar-free gum and the saliva was directly collected in an empty sterile cryotube, with the aid of a sterilized funnel. All samples were stored at $-20^{\circ} \mathrm{C}$ until they were pro- cessed. Regarding the children, four samples of subgingival plaque were obtained from the lingual aspect of deciduous lower second molars, and two, from the buccal aspect of deciduous upper second molars.

\section{Slot immunoblot ${ }^{20}$}

For the assessment of microorganisms, antigens from Actinobacillus actinomycetemcomitans (Aa) (ATCC 43717), Prevotella nigrescens (Pn) (ATCC 33563), Porphyromonas gingivalis (Pg) (ATCC 33277) and Treponema denticola (Td) (ATCC 35405) were utilized, as well as highly specific rabbit antisera absorbed by means of a panel of oral bacteria developed at the Microbiology Laboratory, Dental School, Michigan University - USA, which were kindly provided by Dr. Dennis E. Lopatin. Briefly, the samples were subjected to ultrasonication ( 3 to $5 \mathrm{~s} ; 60 \%$ of power, Kontes Instruments) to disrupt aggregates of dental plaque particles. Nitrocellulose sheets (BA-85; Schleicher \& Schuell) were soaked for 15 minutes in Tris-Buffered Saline (TBS, $0.05 \mathrm{M}, \mathrm{pH}$ 7.4) prior to insertion in the slot blot manifold (Minifold II, Schleicher \& Schuell). Standards of lyophilized pure bacteria diluted in distilled water and samples of undiluted plaque were applied $(10 \mathrm{ml})$ to each manifold slot, which was then evacuated with the gentle application of vacuum. The nitrocellulose sheets were removed from the manifold for further processing. Microbial detection and quantitation were carried out after first immersing the nitrocellulose membrane in TBS containing $0.5 \%$ nonfat dried milk Molico (Blotto) for 30 to $60 \mathrm{~min}$ to block unoccupied binding sites on the nitrocellulose membrane. The appropriate antibacterial antibody diluted in TBS-Tween 20 (0.05\%) containing 0.5\% Blotto was applied and incubated for 1 hour. Following three 5-minute washes in TBS-T, goat anti-rabbit immunoglobulin $\mathrm{G}$ conjugated to alkaline phosphatase (Zymed) diluted in TBS-T-Blotto was applied and incubated for 1 hour. After two 5-minute washes in TBS-T and one 5-minute wash with TBS, BCIP-NBT substrate solution (Kirkegaard \& Perry Laboratories) was applied and color development was allowed to proceed to its maximum. All soakings, incubations and washes were carried out on a rocking table (Hoefer Scientific Co.) at room temperature. Absence of color indicated score 0 , score 1 represented a concentration of at least $2 \times 10^{4} \mathrm{CFU}$ (colony forming units), score 2 , from $2 \times 10^{4}$ to less than $3 \times 10^{5}$ $\mathrm{CFU}$, and score 3 , at least $3 \times 10^{5} \mathrm{CFU}$. To determi- 
Rosa OP da S, Silva SMB da, Costa B, Torres SA, Passanezi E. Periodontopathogens in the saliva and subgingival dental plaque of a group of mothers. Pesqui Odontol Bras 2002;16(4):313-318.

ne the mass of the samples, a lectin assay for carbohydrates was carried out by means of the same slot blot technique with other reagents ${ }^{20}$.

\section{Statistical analysis}

The Mann-Whitney test was employed for the comparison between genders; Wilcoxon test, for the comparison between the mean scores of bacteria in the four sites and in saliva; and Pearson's test, for the assessment of correlations. Statistical significance was established at 5\%.

\section{RESULTS}

On Tables 1 and 2, the mean values and standard deviations of the clinical variables for mothers and children are shown. The results do not present a normal distribution. In the comparison of plaque and gingival indexes of mothers and children, by means of the Wilcoxon test, significant difference $(\mathrm{p}<0.05)$ was found for the gingival index $(z=2.703)$, but not for the plaque index $(z=1.252)$. The same comparison, carried out between male and female children through Mann-Whitney test, did not reveal any differences reagarding plaque index $(U=107.0)$ and gingival index $(\mathrm{U}=101.0)$.

The results of the microbiological assessment prevalence of positivity, intensity of colonization and bacterial distribution in saliva and subgingival sites of mothers - are presented on Tables 3 to

TABLE 1 - Mean values and standard deviations (SD) for the clinical variables of mothers.

\begin{tabular}{l|c|c}
\hline \hline \multicolumn{1}{c|}{ Variable } & Mean & SD \\
\hline Age (years) & 28.4 & 4.49 \\
\hline Number of teeth & 26.3 & 3.51 \\
\hline Plaque index & 1.86 & 0.67 \\
\hline Gingival index & 1.24 & 0.67 \\
\hline Total PD & 1.81 & 0.69 \\
\hline PD of the 4 sites & 4.03 & 1.40 \\
\hline \hline
\end{tabular}

$\mathrm{PD}=$ probing depth.
5. The comparison between the mean scores of bacteria in the four sites and in saliva revealed statistically significant differences $(\mathrm{p}<0.05)$, and saliva always exhibited the highest values.

The microbiological analysis was impaired in children due to the small amount of subgingival dental plaque. Only 19 children (63\%) had material available for the study, as revealed by the carbohydrate assay and, even so, plaque was present in only $48.6 \%$ of the sites. Ten out of 19 children were positive for one ( 6 children), two ( 3 children) or four bacteria ( 1 child).

In the analysis of correlation between clinical and microbiological variables in mothers, significant correlation was observed between PI and PG $(\mathrm{p}=0.000)$, between $\mathrm{PI}$ and $\mathrm{PD}$ of the 4 sites $(p=0.02)$ but not for total PD ( $p=0.069)$; between GI and PD of the 4 sites and total PD ( $p=0.000)$, and between total PD and PD for the 4 sites $(p=0.000)$. Plaque index and GI presented correlation with the presence of all bacteria in the 4 sites and in saliva, except for salivary Aa. Total PD and PD of the 4 sites did not correlate to salivary Aa nor to Aa from the 4 sites, but correlated to the remaining 3 bacteria from the 4 sites. In the children group, a significant correlation was observed between PI and GI ( $p=0.001)$. However, significant correlations between plaque and gingival indexes from both groups were not observed in the analysis of correlation of variables between mothers and children. Children's PI and GI presented significant correlation with mothers' mean salivary scores of $P$. gingivalis and $T$. denticola.

\section{DISCUSSION}

Parents presenting periodontal disease may play a role as a source of infection for their spouses and children. There is no difference between the presence of disease in either of the parents, since the healthy subject may have the periodontopathogens of his/her spouse and transmit them to the child. Thus, the presence of periodontal disease in one of the parents is an indicator of risk for

TABLE 2 - Mean values and standard deviations for the clinical variables - male and female children.

\begin{tabular}{l|c|c|c}
\hline \multicolumn{1}{c|}{ Variable } & Complete sample $(\mathrm{n}=30)$ & Male children $(\mathrm{n}=14)$ & Female children $(\mathrm{n}=16)$ \\
\hline Age & $71.9 \mathrm{~m} \pm 4.72 \mathrm{~m}$ & $71.4 \mathrm{~m} \pm 5.42 \mathrm{~m}$ & $72.4 \mathrm{~m} \pm 4.14 \mathrm{~m}$ \\
\hline Plaque index & $1.64 \pm 0.68$ & $1.64 \pm 0.78$ & $1.64 \pm 0.60$ \\
\hline Gingival index & $0.82 \pm 0.37$ & $0.76 \pm 0.32$ & $0.87 \pm 0.41$ \\
\hline \hline
\end{tabular}


Rosa OP da S, Silva SMB da, Costa B, Torres SA, Passanezi E. Periodontopathogens in the saliva and subgingival dental plaque of a group of mothers. Pesqui Odontol Bras 2002;16(4):313-318.

TABLE 3 - Prevalence (\%) of mothers, sites and saliva positive for the studied bacteria.

\begin{tabular}{l|c|c|c|c}
\hline \multicolumn{1}{c|}{ Bacteria } & A. $a{ }^{*}$ & P. nigrescens & P. gingivalis & T. denticola \\
\hline Sites & $28(93.3 \%)$ & $19(63.3 \%)$ & $20(66.7 \%)$ & $8(26.7 \%)$ \\
\hline Saliva & $30(100 \%)$ & $24(80.0 \%)$ & $21(70.0 \%)$ & $11(36.7 \%)$ \\
\hline Mothers & $30(100 \%)$ & $28(93.3 \%)$ & $24(80.0 \%)$ & $11(36.7 \%)$ \\
\hline \hline
\end{tabular}

*Actinobacillus actinomycetemcomitans.

TABLE 4 - Distribution (\%) of the scores of bacterial detection (0 a 3) in the 120 gingival crevices/pockets of mothers.

\begin{tabular}{c|c|c|c|c}
\hline \hline Scores & A. $a{ }^{*}$ & P. nigrescens & P. gingivalis & T. denticola \\
\hline 0 & $38(31.7 \%)$ & $80(66.7 \%)$ & $72(60 \%)$ & $107(89.2 \%)$ \\
\hline 1 & $44(36.7 \%)$ & $22(18.3 \%)$ & $25(20.8 \%)$ & $10(8.3 \%)$ \\
\hline 2 & $25(20.8 \%)$ & $13(10.8 \%)$ & $16(13.4 \%)$ & $2(1.7 \%)$ \\
\hline 3 & $13(10.8 \%)$ & $5(4.2 \%)$ & $7(5.8 \%)$ & 1 \\
\hline Total & $120(100 \%)$ & $120(100 \%)$ & $120(100 \%)$ & $120(100 \%)$ \\
\hline \hline
\end{tabular}

*Actinobacillus actinomycetemcomitans.

TABLE 5 - Distribution of bacteria in the saliva and subgingival sites of mothers.

\begin{tabular}{l|c|c|c|c}
\hline \multicolumn{1}{c|}{ Bacteria } & saliva (+), sites $(+)$ & saliva $(+)$, sites $(-)$ & saliva (-), sites (+) & saliva (-), sites $(-)$ \\
\hline A. $a{ }^{*}$ & $28(93.3 \%)$ & $2(6.7 \%)$ & - & - \\
\hline$P$. nigrescens & $15(50.0 \%)$ & $9(30.0 \%)$ & $4(13,3 \%)$ & $2(6.7 \%)$ \\
\hline P. gingivalis & $17(56.7 \%)$ & $4(13.3 \%)$ & $3(10.0 \%)$ & $6(20.0 \%)$ \\
\hline$T$. denticola & $8(26.7 \%)$ & $3(10.0 \%)$ & - & $19(63.3 \%)$ \\
\hline \hline
\end{tabular}

*Actinobacillus actinomycetemcomitans.

the colonization of the child by pathogenic anaerobic species ${ }^{8,25}$.

The periodontal status of the mothers evaluated in this study ranged from normal to the presence of periodontitis (Table 1). The mean values of total probing depth did not correctly characterize the sample, but the mean PD of the four sites did, revealing that, in $40 \%$ of the mothers and in $45.8 \%$ of the sampled sites, PD was $\geq 4.0 \mathrm{~mm}$. The plaque and gingival indexes showed remarkable variation: 26 mothers $(86.7 \%)$ presented PI $>1.0$, which means regular hygiene, whereas 17 mothers (56.7\%) presented GI > 1.0, with mild to moderate inflammation. In agreement with the maternal oral hygiene pattern, $70 \%$ of the children presented PI $>1.0$. That was not true for GI, since $80 \%$ of the children exhibited GI $\leq 1.0$. In general, the gingivitis presented by the studied children was mild, tending to moderate (GI $>0<2$ ) (Table 2). In both groups, PI presented significant correlation $(\mathrm{p}=0.001)$ with
GI, but no correlation was observed between groups, regarding those indexes. In the comparison of scores of mothers and children, there was difference as to the gingival index: children presented a significantly lower gingival index, when compared with their mothers. Salvador et al. ${ }^{18}$ (1997) have also reported a strong familial correlation between children aging 6 to 11 years and their mothers, as to PI, which indicates that family habits may be important in the development of periodontal diseases. The smaller overall trend to develop gingivitis exhibited by children may be explained by bacteriological differences related to age, by differences in the immune response, or by both ${ }^{11}$.

The fact that the positivity for putative periodontopathogens in children was coincident with the positivity in their mothers was also observed by other authors ${ }^{1,13,22}$. Researches on transmission demonstrated that even the clonal types of $P$. gingivalis, $A$. actinomycetemcomitans, $P$. intermedia, $P$. nigrescens and other microorganisms may be present in family 
Rosa OP da S, Silva SMB da, Costa B, Torres SA, Passanezi E. Periodontopathogens in the saliva and subgingival dental plaque of a group of mothers. Pesqui Odontol Bras 2002;16(4):313-318.

members, whereas different clonal types are found in people with no familial relation ${ }^{4,10,13,14,17,21,22,23}$. On the other hand, the isolation of the same microorganisms from saliva, tongue, oral mucosa and tonsils of patients with periodontal disease and their spouses $^{1,12,13,14,22}$ suggests that not only saliva, but also direct oral contact may play a role in the transmission of microorganisms.

Taking into account only subgingival sites, the prevalence of mothers positive for the four studied bacteria (Table 3) was lower than that of a group of patients with periodontitis also studied by means of the SIB technique $(100 \%)^{16}$. However, it must be mentioned that $100 \%$ of their sites presented $\mathrm{PD} \geq 4.0 \mathrm{~mm}$. Besides that, they were heavily colonized (scores 2 and 3), unlike the mothers in which score 1 predominated, demonstrating a weakly positive reaction for all bacteria (Table 4). In spite of the lower prevalence, the pattern of occurrence of microorganisms was similar in children: $36.8 \%$, $31.6 \%, 10.5 \%$ and $5.2 \%$ for $A$. actinomycetemcomitans, $P$. nigrescens, $P$. gingivalis and $T$. denticola, respectively. The difficulty to see $P$. gingivalis and $T$. denticola in children aging 5-6 years had already been reported in another study which utilized the same technique and ideal amounts of plaque ${ }^{15}$.

The occurrence and distribution of bacteria in the saliva and subgingival sites of mothers (Table 5) reveal that saliva yielded more positive results and significantly higher scores $(\mathrm{p}<0.05)$ than subgingival sites. Except for A. actinomycetemcomitans, Umeda et al. ${ }^{19}$ (1998) confirmed the superiority of saliva in relation to subgingival plaque in the detection of the presently studied bacteria. For some authors, the presence of these bacteria simultaneously in saliva and in subgingival samples and the presence of the same genetic clones in both samples suggest the diffusion of bacteria from pockets to saliva ${ }^{2,10,19,24}$, which encourages the utilization of saliva for microbiological sampling in periodontics ${ }^{3,6,7,19}$.

Despite the observation that the only child positive for all bacteria was the child of the subject with the worst periodontal condition, and despite the fact

\section{REFERENCES}

1. Alaluusua S, Asikainen S, Lai CH. Intrafamilial transmission of Actinobacillus actinomycetemcomitans. J Periodont 1991;62(3):207-10.

2. Asikainen S, Saarela M. Clonal identity of salivary and subgingival Actinobacillus actinomycetemcomitans [Abstract 1059]. J Dent Res 1997;76:146. that there was almost a correlation between mothers' GI and children's PI ( $p=0.058$ ), it was not possible to associate the presence of bacteria in children with the periodontal status of mothers, which has also been reported by other authors ${ }^{8,25}$. The impossibility was probably related to the poor material provided by the children, and to the few areas with $\mathrm{PD} \geq 4 \mathrm{~mm}$ presented by this group of mothers. Nevertheless, the inverse may be true, according to the correlation found between the scores of $P$. gingivalis and $T$. denticola in maternal saliva and the gingival inflammation observed in the children.

The results of this study demonstrate the presence of periodontopathogenic bacteria in both mothers and children when permanent teeth irrupt, in a frequency pattern that not only suggests the transmission from the mother to the child, but also points out the saliva as a possible vehicle for this transmission. The importance of the presence of bacteria as an indicator of the risk for periodontal destruction in mothers, and the significance of early colonization as a risk factor for periodontal disease in children can only be acknowledged through a longitudinal follow-up of these pairs.

\section{CONCLUSION}

The saliva of the mothers included in this study presents greater positivity and higher scores for $A$. actinomycetemcomitans, $P$. nigrescens, $P$. gingivalis and $T$. denticola than their subgingival samples. It is, thus, able to act as a vehicle for the transmission of those microorganisms.

\section{ACKNOWLEDGMENTS}

The authors thank the graduate students in Periodontics, School of Dentistry of Bauru, University of São Paulo, for the clinical evaluation; Dr. José R. P. Lauris, for the statistical analysis; Dr. Dennis E. Lopatin, for the supply of strains and polyclonal antisera; the directors of the municipal infant and nursery schools Isaac P. Roldan, Rodrigues de Abreu and Gasparzinho; and FAPESP, for the financial grant (1996/7326-1).

3. Asikainen S, Alaluusua S, Saxén S. Recovery of Actinobacillus actinomycetemcomitans, from teeth, tongue, and saliva. J Periodontol 1991;62(3):203-6.

4. Fukui K, Kato N, Kato H, Watanabe K, Tatematsu N. Incidence of Prevotella intermedia and Prevotella nigrescens carriage among family members with 
Rosa OP da S, Silva SMB da, Costa B, Torres SA, Passanezi E. Periodontopathogens in the saliva and subgingival dental plaque of a group of mothers. Pesqui Odontol Bras 2002;16(4):313-318.

subclinical periodontal disease. J Clin Microbiol 1999;37(10): 3141-5.

5. Greenstein G, Lamster I. Bacterial transmission in periodontal diseases. A critical review. J Periodontolol 1997;68:421-31.

6. Könönen E, Jousimies-Somer H, Asikainen S. Relationship between oral gram-negative anaerobic bacteria in saliva of the mother and the colonization of her edentulous infant. Oral Microbiol Immunol 1992;7(2):273-6.

7. Könönen E, Jousimies-Somer H, Asikainen S. The most frequently isolated gram-negative anaerobes in saliva and subgingival samples taken from young women. Oral Microbiol Immunol 1994;9(2):126-8.

8. Könönen E, Jousimies-Somer H, Wolf J, Asikainen S. Influence of maternal periodontal status on colonization of suspected periodontopathogens in children [abstract 469]. J Dent Res 1995;74:469.

9. Löe H. The gingival index, the plaque index and the retention index systems. J Periodontol 1967;38(6 suppl):610-6.

10. Mättö J, Saarela M, Von Troil-Linden B, Alaluusua S, Jousimies-Somre H, Asikainen S. Similarity of salivary and subgingival Prevotella intermedia and Prevotella nigrescens isolates by arbitrarily primed polymerase chain reaction. Oral Microbiol Immunol 1996;11(6):395-401.

11. Matsson L. Factors influencing the susceptibility to gingivitis during childhood - a review. Int $J$ Pediatr Dent 1993;3(3):119-27.

12. Petit MD, Van Steenbergen TJ, De Graaf J, Van Der Velden $\mathrm{U}$. Transmission of Actinobacillus actinomycetemcomitans in families of adult periodontitis patients. $J$ Periodontol Res 1993;28(5):335-45.

13. Petit MD, Van Steenbergen TJ, Scholte LMH, Van der Velden U, De Graaf J. Epidemiology and transmission of Porphyromonas gingivalis and Actinobacillus actinomycetemcomitans among children and their family members. A report of 4 surveys. J Clin Periodontol 1993;20(9):641-50.

14. Petit MD, Van Steenbergen TJ, Timmerman MF, De Graaf J, Van der Velden U. Prevalence of periodontitis and suspected periodontal pathogens in families of adult periodontitis. J Clin Periodontol 1994;21(2):76-85.
15. Rosa OPS. Prevalência de microrganismos na placa subgengival da dentição decídua. [Tese de Livre Docência]. Bauru: Faculdade de Odontologia de Bauru da USP; 1995.

16. Rubira IRF. Pesquisa de bactérias bucais em amostras de placa subgengival de indivíduos com periodonto normal e de portadores de periodontite através da técnica do "slot immunoblot". [Tese de Doutorado]. Bauru: Faculdade de Odontologia de Bauru da USP; 1994.

17. Saarela M, Von Troil-Linden B, Torkko H, Stucki AM, Alaluusua S, Jousimies-Somer H, et al. Transmission of oral bacterial species between spouses. Oral Microbiol Immunol 1993;8(6):349-54.

18. Salvador SL, Grisi M, Romanelli RG, Silva Netto CR, Schork NM, Bretz WA. Similarities of periodontal clinical and microbiological parameters in mother-child pairs. Braz Dent J 1997;8(2):99-104.

19. Umeda M, Contreras A, Chen C, Bakker I, Slots J. The utility of whole saliva to detect the oral presence of periodontopathic bacteria. J Periodontol 1998;69(7):828-33.

20. Van Poperin N, Lopatin DE. Slot immunoblot assay for detection and quantitation of periodontal disease-associated microorganisms in dental plaque. J Clin Microbiol 1991;29(11):2554-8.

21. Van Steenbergen TJ, Menar C, Tijhof CJ, Mouton C, De Graaf J. Comparison of three molecular typing methods in studies of transmission of Porphyromonas gingivalis. J Med Microbiol 1993;39:416-21.

22. Van Steenbergen TJ, Petit MD, Scholte LHM, Van der Velden U, De Graaf J. Transmission of Porphyromonas gingivalis between spouses. J Clin Periodontol 1993;20(5):340-5.

23. Van Steenbergen TJ, Bosch-Tijhof CJ, Petit MD, Van der Velden U. Intra-familial transmission and distribution of Prevotella intermedia and $P$. nigrescens. J Periodont Res 1997;32(4):345-50.

24. Von Troil-Lindén B, Saarela M, Mättö J, Alaluusua S, Jousimies-Somer H, Asikainen S. Source of suspected periodontal pathogens re-emerging after periodontal treatment. J Clin Periodontol 1996;23(6):601-7.

25. Watson MR, Bretz WA, Loesche WJ. Presence of Treponema denticola and Porphyromonas gingivalis in children correlated with periodontal disease of their parents. J Dent Res 1994;73(10): 1636-40. 